Ankara Üniversitesi Ĕ̈itim Bilimleri Fakültesi Dergisi, yıl: 2004, cilt: 37, sayı: 1, ss.141-155

Ankara University, Journal of Faculty of Educational Sciences, year: 2004, v: 37, issue: 1, pp.141-155

\title{
Çocuklar ve Küreselleşme ${ }^{1}$
}

\section{Çeviren}

\section{Nihal AHİŎLLU*}

\section{Giriș Notu}

$\mathrm{Bu}$ makale, bahar 2001'de Polonya Lodz Üniversitesinde düzenlenen küreselleşme konulu bir konferans için yazılmıştır. Pek çok durumda çocuklar, küreselleşme bağlantılı tartışmalara nadiren dahil edildikleri için onlarla ilgili konuların gündeme getirilmesinin daha uygun olacağını düşündüm. Bu makale, küreselleşmenin bütün kültürlere ulaşma olasılığının olup olmadığ 1 , nerede reddedileceği ya da tamamen yeni bir şey mi yoksa Batı dünyasında uzun süredir devam eden bir sürecin dünyanın geri kalanına yayılması mı olduğu gibi önemli sorularla ilgilenmemektedir. Küreselleşmedeki mevcut eğilimleri açıklamaya yönelik bir anlayışın temeli olarak Birleşik Devletler tarihini kullandığım analiz yöntemi, benim sonuncu kümeye dahil olduğumu gösterse de makale bu stratejiyi, son soruya yanıt olarak değil de ilgili pek çok konuyu aydınlatma aracı olarak kullandığımı göstermektedir. Bu sorularla ilgili önemli tartışmaları, büyüme ekonomisi ile ilgilenen uzmanlara bırakıyorum ${ }^{1}$. Bunun yerine ben, özel bir tarihsel yapı içerisinde derinliğine yazarak, Amerikalı tarihçilerin varolan tartışmayla ilgili bazı katkılar sağlayacağına ve toplumsal tarihçilerin konumlarının da varolan büyük gelişmelere yönelik görüş bildirmeye uygun olduğuna inanan biri olarak yazıyorum.

Çocukların ve çocukluğun, günümüzde küreselleşmeyi tartışanların gündeminde olmaması çok tuhaftır. Çocuklar küreselleşme hakkındaki Batı duyarlılığının kesinlikle bir parçasıdır ve çocukluk, özellikle küreselleşme siyaseti içerisindeki kültürel tartışmanın hassas bir düğüm noktasıdır. Umut ediyorum ki, çocukluk tarihini anlamanın, küreselleşme tartışmalarının, pek çok çocuk etkilendiği ve etkileneceği için, hem daha gerçekçi hale gelmesine hem de medyanın küreselleşmeye yönelik çatışmalara yer vermesiyle uyanan "tuhaf" Batı duyarlılığına alışılmasına yardım edecektir. Çocuklar bu tartışmanın her yerinde olmalarına karşın hiçbir zaman seslerine kulak verilmemiş ya da kendilerine hitap edilmemiştir.

\section{Çocukların Küreselleşmenin Konusu Haline Gelmesi}

Tayland'da Fransız turistler tarafından kiralanan erkek ve kız fahişe çocuklar, internetteki çocuk pornografisi, Amerikan giysileri için ipek yapan 5 yaşındaki tekstil işçileri, Milano kaldırımlarında kendilerine parlak bir gelecek planlarken şiddete uğrayan ve tecavüz edilen Doğu Avrupalı ergen kızlar: Bunlar, ekonomi küresel bir ağ haline

\footnotetext{
${ }^{1}$ Fass, P.S. (2003). Children and globalization, Journal of Social History 36 (4), 963-977.

* Arş.Gör., Ankara Üniversitesi Eğitim Bilimleri Fakültesi Eğitimde Psikolojik Hizmetler Bölümü
} 
geldiği ve bilgi iletişimi araçlarımız, tüm köy ve küçük yerleşim birimlerine kadar ulaştığ için, günümüzde artık sürekli karşılaştığımız şaşırtıcı görüntülerdir. Son derece korunmasız insanlara yönelik bu saldırılar karşısında dehşete düşmekte ve kendimize bunun, geleceğe dönük bir felaket habercisi olup olmadığını sormaktayız. Yaşadığımız gezegen küçüldükçe, çocuklarımızı, zengin ve yoksul uluslar arasındaki giderek açılan ve alabildiğine büyük uçuruma kurban mı edeceğiz?

Çocukluk, hem evrensel bir deneyimdir hem de kültürlere özgüdür. Her toplumun varlığını sürdürebilmesi için çocuklarının olması, onları yetiştirmesi gerekir ve her birinin de çocukları korumaya yönelik kendine özgü yöntemleri vardır. Her kültür, çocukların neye benzediğine ilişkin görüşlerini ve kendi geleceğine dönük kültürel vizyonunu gerçekleştiren çocuklarla ilgili uygulamalarını göstermede kendine özgü yöntemler tasarlarken, bir gelişim evresi olarak çocukluğu farklı bir biçimde tanımlar ve bölümlendirir. Bunun ötesinde, her birimiz bir çocukluk yaşadık ve bu yüzden çocukluğun ne olduğu ve neye benzemesi gerektiği ile ilgili bir imgeye, duygusal olarak sıkı sıkıya bağlıyız. Dolayısıyla çocukluk, kritik bir toplumsal çatışma noktası, önemli bir kültürel özerklik testi ve küreselleşmenin anlamlarını ve sonuçlarını düşünürken hepimiz için temel bir duygusal başvuru noktasıdır.

$\mathrm{Bu}$ nedenle, küreselleşmenin bedellerine ilişkin en çarpıcı görüntülerin konu olarak çocukları ele alması şaşırtıcı değildir. Ve ben inanıyorum ki, küresel bütünleşmeye yönelik varolan bask1, çocukluk dönemine özgü uygulamalarda toplumlara göre özel birtakım farklılıklara yol açacaktır ${ }^{2}$. Ayrıca bu değişim eğiliminin, kültürün olduğu kadar bireysel belleklerin de yaratıldığı en ilkel noktayı da etkileyeceğini ve en üst düzeye de çoğunlukla ulusal tepkilerde ulaşacağını bekleyebiliriz. Bunun iki nedeni var: Birincisi, çocukluk, toplumsallaşma için önemli bir dönüm noktasıdır ve bu nedenle çocukluğun, her toplumun kendi kimliğini koruma yolu olarak stratejik bir rolü vardır. İkincisi, modern Batı toplumlarında özellikle çocuklara ağır bir duygusal anlam verilmiş olması ile bağlantılıdır. Gerçekten de Avrupa-Amerika kökenli Batıdan bu çeşit bir duygusal yansımanın olması nedeniyle, yakın geçmişte çocukluk ve onunla ilgili şeyler, sıklıkla, bizim konunun bütün yönleri ile ilişkili çok yoğun kültürel kaygıya ve acı duyduğumuz durumlara yol açmıştır. Diğer bir anlatımla çocukluğa, sosyolojik ve antropolojik bir alan olması yanında çok büyük bir sembolik anlam da yüklenmiştir. Seçebilecekleriniz arasından sadece birini örnek olarak vereceğim. 1980'lerde Birleşik Devletlerde ve 1990'larda da Avrupa'nın pek çok yerinde, küçük çocuklarla cinsel ilişkiye girme, çocukların cinsel istismarı ve çocuk cinayetleri ilk defa görülmeye başladı ve yaygın bir popüler histeriye neden oldu. $\mathrm{Bu}$ tepkilerle, çocuklara yönelik gerçek şiddet olayları genellikle orantısız olsa da bu tepkiler, çok genel bir savunmasızlı̆̆ gösterir ve çoğunlukla polis, ekonomi, aile içindeki değişimler, yeni cinsel uygulamalar ve toplumsal cinsiyet rolleri gibi konuları içeren ve kesinlikle daha az üzerinde durulan şikayet ve korkuları ifade etmenin güçlü yollarıdır ${ }^{3}$.

Hem küreselleşmenin çocukları nasıl etkilediğini hem de çocukluk imgesini neden bu kadar önemsemeye başladığımızı anlamak için, bu sorulara bazı yanıtlar bulabileceğimiz Amerika'ya özgü toplumsal yaşam tarzlarının kimi yönlerini ele almak 
istiyorum. Yaşlı "Yeni Dünya"nın bu bağlamda incelenmesi, bu tartışma için alışılmışın dışında olsa da iyi bir başlangıç noktasıdır. Bugün Birleşik Devletler, yeni "Yeni Dünya"nın yaratılması sırasında küreselleşmeyi zorunlu kılan en güçlü itici güç olması yanında küreselleşmenin ilk örneklerinin görüldüğü bir tür küçük evrendir. Ne de olsa, piyasa güçleri sayesinde tüm kültürel formların egemenlik alanının hızla genişlediği ve iletişim araçlarının etkisinin arttığı günümüzde küreselleşme, en erken Batı'da ve en çarpıcı biçimde Birleşik Devletlerde görülen büyüme modellerini kullanır. Bu noktada ilk göze batan şeyler, hızlı ekonomik büyüme, göç, halkların karışımı (regionalism), yerelleşmenin (localism) sona ermesi ve farklı değer sistemlerinin karşı karşıya gelmesidir. Birleşik Devletler, son 150 yıllık kendi tarihsel geçmişinde bütün bunları yaşadı. Ne de olsa Birleşik Devletler, dinamik kapitalist ekonomisi yanında çok geniş olanaklara da sahip olması nedeniyle milyonlarca göçmeni topraklarına, fabrikalarına, atölyelerine ve okullarına çeken bir ulustur. $\mathrm{Bu}$ nedenle bu süreçte çocukları konu alan, özellikle anlamlı olan üç noktaya değinmek istiyorum: Çocukların çalıştırılması konusu, çocukluğun gelişmesinde oyunun rolü, cinsellik sorunu. Bunlar ayrıca güçlü bir sembolik "ateşleme mekanizması"na sahip bu çağa özgü "gençlik karmaşası" olarak adlandırmak istediğim şeyi de açıklar.

\section{Çocukların Çalışması}

Amerika'nın ilk maliye bakanı Alexandar Hamilton ülkesinin geleceğini biçimlendirme hayalleri kurarken ve bununla ilgili yazılar yazarken, o hayallerde çocuklara da yer vermeye yönelik hiçbir duygusal kaygı taşımıyordu ${ }^{4}$. Aileleri ile birlikte yaşayan çocukların zaten ulusal demiryolları ve fabrikalarda çalışacağını varsayıyordu. Neden olmasındı ki? 18. yüzyılın sonunda, Hamilton geleceğin Amerikası ile ilgili raporunu yayınladığında yaşları 5-6 kadar küçük olan Amerikalı çocukların, aileleri ile birlikte çiftliklerde, köy dükkanlarında ve hatta devlete bağlı bakım evlerinde çalıştıkları görülebiliyordu.

Bugün ergen olarak adlandıracağımız 14 yaşındaki kızlar, ailelerinden uzakta, yalnız ve katı sınırlılıklar altında gün doğumundan batımına kadar saatlerce Lawrence, Lowell ve Holyoke, Massachusetts'deki iplik fabrikalarında millerce iplik işliyorlardı. Önceleri böyle bir işleri olduğu için memnundular ve hatta Charles Dickens ve onlara acıyıp ziyaretlerine gelenler, sağlklarının iyi olduğunu ve çok istekli olduklarını doğruluyorlard1. $\mathrm{Bu}$ çocuklar 1850 'lere kadar kendilerini, sanayi işçiliğinin küçük düşürücü ayrıcalıkları olarak görmedikleri gibi durumlarının kölelerden daha iyi olmadığını da henüz göremiyorlard ${ }^{5}$.

Amerikalıların köleler için üzülmeye başladığı, Harriet Beecher Stowe'nin, Amerikalıların aile değerlerine ve insanlık dışı davranışları ile hem beyazlar hem de siyahlar için çalışan bir derneğe dikkatimizi çektiği zamanlar, çocuklukla ilgili düşüncelerimizi gözden geçirmemizi sağlayan önemli dönüm noktalarından biri olmuştur. Stowe bunu yaparken, Batı dünyasına, yeni bir duygusallık anlayışının oluşmasını sağlayan saf, masum bir çocukluk resmi sunmuştur. O dönemin birçok insana tanıdık olan pek çok başka imgeleri ile birlikte Küçük Eva ve Tom Amca ve Topsy, çocukluğu değerli 
olan ve dikkatli biçimde korunması gereken bir şey yapmıştır. 19. yüzyılın ortalarında, John Locke'ın yaklaşık iki yüzyıldan beri varolan ve bazılarının iyi bildiği "tabula rasa"sı, çocukluğun temellerini açıklama biçimi açısından büyük bir yankı uyandırmıştır. Aynı dönemde, bir zamanlar 6 yaşındaki çocukların çalıştırılmasının normal görüldüğüne ilişkin su götürmez varsayımlar, artık bir sona ulaştı. Dinle, politikayla ve borçlu olduğumuz diğer şeylerle ilgili görüşlerimizin ortak bir payda altında ve tamamen yeni olan birleşimi, sadece kendi çocuklarımızı değil başka insanların çocuklarını da ön plana çıkarttı. O döneme kadarki görüşlerimizin belli bir düzeyde değişmesi ile oluşan bu yeni anlayış, bugün Hindistan, Afrika ve Tayland'daki çocuklar ve Slovenya'daki ergenlerle ilgili haberlere nasıl tepki vereceğimizi belirlemeye devam ediyor.

$\mathrm{Bu}$ anlayışı ve onu oluşturan etmenleri açıklamak için bu konu üzerinde bir süre durmakta yarar var. Çünkü böylesi bir anlayış, Batılı gözlemcilere günümüzde dünyanın değişik bölgelerinde baskıya maruz kalan çocuk haberleri ile gözyaşı döktürülmesinin nedenine dikkatimizi çekmekle kalmaz, ayrıca gelecekte ekonomik büyüme ile bağlantılı hangi konuların daha önemli hale gelebileceğini de gösterir. Bu anlayışın merkezinde, sosyolog Viviana Zelizer'in "paha biçilmez çocuk" olarak adlandırdığ ekonomiden bağımsız ve herhangi bir değer biçilemeyecek çocuk vardır ${ }^{6}$. Çocuğa verilen bu değer, aileleri ve toplumu onun iyiliği için çalışmak zorunda bırakan duygusallık düzeyinde ölçülmüştü. Çocuğun ekonomik hesaplarda yer alabildiği ve hatta katkısının küçük de olsa önemli olduğu bir bütçeden, yasal hesaplamaların onun daha iyi korunabilmesi ve bunun için birtakım önlemler alınabilmesi doğrultusunda düzenlendiği bir bütçeye geçiş sürecinde toplum, paradigmal bir değişme yaşamıştır. İnanıyorum ki bu değişme, çocuğu ilkel ve kaderine terk edilmiş olarak gören anlayıştan (erken dönem Amerika'daki Kaderci çocuk anlayışı), onu masum ve Tanrı'nın krallığının "melek yüzlü varlığı" olarak gören (Kraliçe Viktorya Dönemi) anlayışa geçiş sürecindeki değişme kadar anlamlıydı. O masum çocuk, 18.yüzyıl kadar erken bir dönemde ortaya çıkmış olsa da o dönemde bu masumiyeti korumaya yönelik çok az, uygun toplumsal ve yasal koşullar söz konusuydu ${ }^{7}$. Bu değişmenin, 19.yüzyılda çocukların ekonomik gerçeklik boyutundan duygusal gerçeklik boyutuna geçmesinde payı olmuş ve bu değişme, çocuğun değeri ile ilgili anlayışlarda öncekilerden oldukça farklı birtakım değişikliklere neden olmuştur. Batı, çocukları açgözlü pazar ekonomisi makinasından kurtarıp onlara öncekinden farklı bir değer verip yatırım yaparak, çocukluğu bir masumiyet alanı içine yerleştirmiştir. $\mathrm{Bu}$ durum belirtilen iki değişimin, çocukları kavramsallaştırma ve özellikle beyaz orta sınıf Amerikalıların çocukları yetiştirme biçimlerinde farklılıklara yol açmasından sonra ve üstelik sadece Batıda değil dünyanın değişik bölgelerinde de gözlenen bir durumdu.

Günümüzde, dünya üzerindeki tüm çocuklara kimi zaman puslu gözlükler altından bakıyoruz. Tekrar etmem gerekirse, bu yeni değerler ve inançlar sisteminde çocuk, ekonomik olarak sağladıklarından dolayı değil, onun toprağı işlemesinin aileye verdiği doyumdan dolayı önemliydi. Kendi değeri, onun duygusal olarak iyi ve fiili olarak hazır olması fikrine dayandığı için çocuk, bu durumda daha fazla şey bekleyebilir. Çocukluk, yetişkinlerin çocukları korumak zorunda olduğu bir masumiyet ve 
savunmasızlık dönemi olarak diğer gelişim dönemlerinden ayrılmıştır. Çocuk, sahip olduğu özel birtakım niteliklerle ailesine katkıda bulunduğu ve topluma da daha iyi bir gelecek vadettiği için çocuk olmaktan hoşlanıyor olabilirdi. Bu yıllarda, çocukların bu kişilik özelliklerini vurgulayan ve yeni yeni gelişen psikoloji disiplini ve duygusal yaşamı araştıran başka bilim alanları da ortaya çıkmaya başladı. Çocuk sadece piyasaya ait matematiksel hesaplardan çıkarılmakla kalmamış, çocukluğa Batı değerlerinin kutsal bir şeymiş gibi sayg1 gösterdiği bireysellik temelleri içinde de yatırım yapılmıştır. Ayrıca çocukluğun, geleceğin biçimlendirilmesindeki temel rolünü vurgulayan görüşler sayesinde, eğitimde de demokratik yönde birtakım gelişmeler gözlenmiştir.

Bana göre bu çocuklukla ilgili saygın bir görüştür ve uygar yaşamı tanımlayan pek çok nitelikten biridir. Ancak bu açıkça, Batıya özgü bir uyanıştır ve uyanışın yarattığ 1 sonuçlar, Batının tüm sosyokültürel değer ağına yayılır. Günümüzde ekonomik değişimlerin, küreselleşmenin zorlukları ile baş etmeye çalışan karmaşık kültürler üzerinde ne tür etkilerinin olacağ 1 konusu üzerinde dururken, bu durumu aklımızın bir köşesinde tutmak iyi olabilir. Amerikalılar çocuklarını, çocukluk vizyonlarının iliştirilmiş olduğu bir dizi inanç ve pratiğin gereği olarak, ekonomik pazardan çekip çıkarmışlardır ${ }^{8}$.

Birleşik Devletlerin savaş sonrası nüfusu, bilime ve çocuklukla ilgili bu düşüncelere oldukça bağlı, eğitimin önemine sadık kentsel orta sinıftan oluşuyordu. Kendine özgü içsel küreselleşme yorumu doğrultusunda, bu büyük kuzey orta sınıf duyarlılı̆̆1, özellikle patlayan ekonomisi ve açı sınırları nedeniyle Amerikanın sunduklarına kapılıp gelen bir dizi göçmen grup ile uğraşmak zorunda kalmıştır. Kendi sınırları içinde Birleşik Devletler o dönemde hala, hem çocukların rol ve görevlerine ilişkin görüşleri eskiden kalma bir dizi değerden oluşan sanayileşme öncesi kırsal nüfus tabakalarını hem de ilk köleler ve onların çocuklarının olduğu büyük bir grubu içermekteydi. Bütün bu çocuklar, çocukluğa ilişkin yeni vizyonun mirasçıları ve kimi zaman da kurbanları oldular. Böylelikle 19. yüzyıl sonlarında bu yeni vizyonu gerçekleştirmeyi amaçlayan farklı kurumlar oluşturuldu. Küreselleşmenin bu ilk biçiminde, sonuçta galip gelen görüş, burada Batı görüşü olarak sözünü ettiğimiz görüştü. Olumsuz sonuçları yanında bunun birtakım olumlu sonuçları da görüldü. Bu olumlu sonuçlardan bazıları, bu vizyondan çıkan ve amacı çocukları korumak, eğitmek ve barındırmak olan kurumlar düşünüldüğünde görülür. Liste uzun olmakla birlikte bu vizyondaki en önemli bileşenler; Çocuklara Yardım Derneği, Çocukları Şiddetten Koruma Dernekleri, kimsesizleri korumaya yönelik yurtlar, evlat edinme ve yetiştirmeye yönelik hizmetler, çocuk mahkemeleri ve tutukevleri, spor klüpleri ve oyun alanları, küçük yerleşim alanları ve kiliselere bağlı toplumsal merkezler ve hepsinin ötesinde yeniden biçimlendirilen ve yenilenen zorunlu okullar ve benzeri reform okullarıdır.

$\mathrm{Bu}$ kurumlar, değerleri ve inançları vizyon standartlarına uymayan insanları korumak, desteklemek, değerlendirmek ve belirlenen vizyona uymaya zorlamak için oluşturulmuştur. $\mathrm{Bu}$ kurumlar, bazılarının değerlerine uyan ama pek çoğunun alışkanlıklarına uyması gerekmeyen standart bir çocukluk resmi oluşturmakla işe başladı. 20. yüzyılda bu kurumlar pek çok çocuğun yaşamının önemli bir bölümünde çok etkili olmuştur. Son dönem tarihçilerin çoğu övgüye değer bu kurumların sağladığı yararların 
çok azını yazmıştır. Yoksul ve yabancı çocukların korunması, genellikle bu çocukların ailelerini, onların değer ve uygulamalarını kınama aracı olarak hizmet etmiştir ${ }^{9}$. Geçen 50 yıl boyunca, Lionel Trilling, aydınlanmacı ve kalkınmacı liberal gücün nasıl olup da kontrol etmeye yönelik bir baskıya neden olabildiğini araştırmıştır. Belirtilen durum, çocukları koruma doğrultusunda gösterilen duyarlılığın yanlış olduğu anlamına gelmedi; aksine bir kişinin kendi çocuğu dışında farklı insanların çocuklarıyla ilgilenmesinin başka bazı duyguları da besleyebileceği anlamına gelir. Bu biçimde eleştirilen ve dışlanan insanların, bu süreçte çatışma, aşağılanma ve öfke yaşamaları olasıdır ${ }^{10}$.

Yukarıda açıklanan durum, bugün Birleşik Devletlerde gördüğümüz pek çok şeyin aslında birçok mücadeleden sonra var olduğu anlamına gelmektedir. Polonya, İtalya, Yunanistan ve İrlanda'dan gelen göçmenler; çocukluk, çocuk eğitimi, dinsel eğitim ile ilgili vizyonlarını, yetişkinliğin tüm boyutlarına ve özellikle kuşaklararası ilişkiler ve bu ilişkilerin getirdiği birtakım zorunluluklar içerisine yerleştirmeye çalışırken; çocuklarını, geçmişlerinden, papazlarından, kilise kurallarından ve ailelerin yükünü hafifletmesi beklenen işlerden uzaklaştırmaya çalışan bu yeni kurumlara, uygulanan eğitim yöntemlerine ve çocuklukla ilgili yeni tanımlara karşı çıktılar. Gelecekle ilgili vizyonları, ailelerin çocuklara öğrettiklerinden oldukça farklı olan bu kurumlar, aileye duyulan saygıyı da ortadan kaldırdı. Görünen o ki, bu ekonomik olanaklar aileleri çocuklarının geleceği üzerindeki kontrolü başkasına devretmeye zorlayan yeni bir dünyaydi.

Çocukları üzerindeki kontrollerini kaybedenleri daha iyi anlayabilmek için, süreç içinde yukarda belirtilen değişikliklerin sadece kendi amaçlarına ulaşmak için Birleşik Devletlere gelenlerce nasıl yaşandığını gösterecek şöyle bir örnek verilebilir. Birleşik Devletlerin kuzeydoğusundaki İtalyanlar, y1llarca, zorunlu kurumsal eğitime olduğu kadar çocukluğun ergenliği de içine alacak biçimde genişletilmesine karşı koymuşlardır. Onlara göre, çocuklar çalışarak daha yararlı olabilecekken eyaletin zorladığı yasalar nedeniyle okulda zamanlarını boşa geçirmektedirler. Connecticut benzeri eyaletlerde, resmi görevliler, "Her yıl, çocukları okula gitmeyen ailelerin pek çoğunun, çocuklarını çalıştırarak onlara göz göre göre kötülük yapılmasına izin veriyor olmalarından ve bu hatalarını fark etmediklerinin kesin olduğundan" yakınmaktaydılar. Aynı bölgelerde aileler, Amerikan yaşamının oyundan başka bir şey yapmayan çocuklarını tembelliğe sürüklediğinden şikayet ediyorlardı. İtalyan bir anne şu şekilde yakınıyordu: "Bir okulun yanından geçtiğinizde duyduğunuz tek şey şarkı, dans sesleri ya da oyun oyun oyun". İtalyan bir baba ise bu durumu başka bir biçimde ifade etmektedir: "Eğer erkek çocuk parlak ve zeki ise bu yapılanlar iyi, ama daha sonrasında o çocuk artık ailesine yeterince sayg1 göstermez. Böyle bir çocuğun hiçbir değeri olmayacaktır. Burada Amerikalı çocuklarla ilgili bir sorun var. O da, okulların onlara, ailelerine saygılı olmayı öğretmiyor olmasıdır" "11. Aileler, eski disiplin yöntemlerini ve ekonomik bir birim olarak eskiye dayanan "ailenin ortak iyiliği" anlayışını sürdürmeyi ümit ederken, bunun aksine resmi görevliler çocukların korunması, ailelerinin dil ve kültürel alışkanlıklarından uzakta eğitilmeleri, kendilerini ifade etmek için oyun oynamaları gerektiğinde 1srar ederler. 
Otoriteyle olan bu savaş, daha çok işle bağlantılı konularda açığa çıkmıştı ve küreselleşmeyi Amerika sınırlarını da aşan çok daha büyük bir ölçek üzerinde ele aldığımızda, bu noktayı akılda tutmakta yarar var. Bununla birlikte, günümüz çocuklarından, Çin'de ayakkabı sektöründe, Hindistan'da giyim sektöründe beklenen ve bizi rahatsız eden işgücü talebi, kendi deneyimlerimizi bir tarafa bırakıp madalyonun diğer tarafından baktığımızda, küreselleşme ile bağlantılı inkar ettiğimiz olumsuzlukları içeren değişim sürecinin ilk evresi olabilir. Çocukların ev dışında işgücü olarak kullanılmasının, son aşamada, çalışmanın toplumsal olarak ayıplanacağı bir gelişim modeline neden olup olmayacağını kestirmek şu an için kesinlikle zordur. Birleşik Devletlerde, pek çok etkenin bir araya gelmesi sonucu çocuk işçiliğini kınayan, çocukluğa yönelik özel bir tür ilginin oluştuğunu iddia etmiştim. Ancak bunun, Batı gözlükleri ile bakan uluslararası kuruluşların boykot edilmesine neden olacağını varsaymak da gerekir.

Pek çok biçimde ekonomik büyüme, çocuk emeğini, kullandığg yeni ve karlı yollarla daha kabul edilebilir hale getirirken, şu ana kadar gördüklerimiz kesinlikle küreselleşmenin ortaya çıkardığ 1 değişimlerin ilk göze çarpan yönleridir. Bu evrede, çocukları iş yaşamına her geçen gün daha fazla çeken aynı güçler, onların yaşamlarını Batıdaki gözlemcilerin gözleri önüne sermiştir. Bunun sonucu olarak çeşitli uluslararası insan hakları organizasyonları, bizi dehşete düşürecek kadar ağır işlerde çalışan çocukların serüvenlerini sergilemeye başladı. $\mathrm{Bu}$ durum, çoğunlukla üniversite kampüslerinde, öğrencilerin, bu çocuklar tarafından üretilen malların boykot edilmesine yönelik mitingler düzenlemelerine neden olmuştur. $\mathrm{Bu}$ boykot çağrıları, uluslararası ticaret kuruluşlarını yeni ve farklı kontrol mekanizmaları kullanmaya ikna edebilir. Sahip olduğumuz vizyon, bizim bu çocukların çalışmasını değil eğitilmesini istememizi gerektirir. Biz, bir çocuğun düşük ücretle çalıştırılmak yerine oyun oynama ve öğrenme hakkı olduğuna inanıyoruz. Bu nokta bizim için, 20. yüzyılın başında Birleşik Devletlere gelen İtalyan ailelerin yaşadığından farklı olmayan bir dönüm noktasıdır. Onlar açısından çocuklarının bu malları üretmelerinin, ailelerine yardım etmelerinin ve bunu yaparken büyüklerine sayg1 göstermelerinin ve büyüklerine boyun eğmelerinin ne sakıncası olabilirdi? Bize göre bu, salt bir sömürüdür ve üzerinde durduğumuz asıl nokta, ailelerin çocuklarını bu biçimde kullanma haklarını kontrol etmektir.

Buna ek olarak diğer bir tartışma noktası, küreselleşen ekonomiye çocukların tarafından yani toplumsal cinsiyet çatışması doğrultusunda bakmaktır. 20.yüzyıl başındaki çocuğa 19.yüzyıl sonundaki prizmadan baktığımızda, bir değil iki mercek takarız. Buna göre, Birleşik Devletlerde, çocukları korumaya yönelik eğilimler, kızları olduğu kadar erkekleri de kapsamaya başlamış ve böylece çocuklar, gelecekteki gelişimleri açısından önemli olan kendini ifade etme ve eğitim görme firsatı elde etmişlerdi. Ancak 19. yüzyıl sonundaki büyük göçte, Birleşik Devletlere gelen çocukların ait oldukları toplumların ve küreselleşme güçlerinin etkisi altındaki günümüz toplumlarının büyük çoğunluğunda, kızlar kendilerine özgü çok sınırlı bir koruma alanına sahiptiler. Bununla birlikte bu toplumlarda kadınlar, Birleşik Devletlerin kendi kadınlarına daha önce verdiği ifade özgürlüğünü yeni yeni kullanıyor ve yeni yeni onlarla 
eşit hale geliyorlardı. Birleşik Devletlerdeki İtalyan ailelerin, kızlarının, sadece erkeklerle flört etme firsatları daha çok olduğu için okula gittikleri konusundaki ısrarları şaşırtıcıydı. Bir anababa şöyle diyordu: "13-14 yaşındaki kızların, zamanlarının çoğunu okulda geçirmeleri, bizi Amerika'ya geldiğimize pişman etti" ${ }^{12}$. Günümüzde küreselleşmenin, toplumsal cinsiyetle ilgili konularda, hem çalışan kızların ataerkil değerler için ciddi bir tehdit oluşturacağı toplum yapıları içinde, hem de dünyadaki tüm kadın ve genç kızların yaşam kalitelerini arttırmak amacıyla oluşturulmuş kadın hakları savunucusu kurum ve kuruluşlar arasında ciddi anlaşmazlıklara neden olması beklenebilir.

\section{Tüketim ve Oyun}

$\mathrm{Bu}$ konudaki tartışma sadece bir evreden oluşmaktadır. İkinci evre, tartışmayı kültürel ve evrensel başka noktalara götüreceği için ona değinmeyeceğiz. Çocukların kazandığ 1 ya da kazanabileceği, bununla birlikte bize göre küçük ve anlamsız olan paranın, kendine özgü zarar verici yönleri vardır. Mevcut paranın çekiciliğinin ve Batı alışkanlık ve uğraşlarına yönelik korunmasızlığın televizyon kanalları yanında internet aracılığıyla da artmasıyla, küreselleşmenin yeni yüzleri ile karşılaşan çocuklar kendilerine, kendi kazandıkları para ile elde edebilecekleri McDonalds'a gitmek, kaset ve cd'ler almak, en hipi Batı kıyafetlerini giymek gibi zevklere ulaşamama nedenlerini sormaya başlayacaklardır. Bu durum beklendiği gibi 1890'lar kadar erken bir dönemde, Amerika'ya ilk göç eden ailelerin oğullarının ve hatta kızlarının başına gelmişti. $\mathrm{Bu}$ noktada, yaşlı dünyanın ergen çocukları; eğlence parklarına, dans salonlarına ve en sonunda da yeni dünyanın sinemalarına gitmeye başladılar. Çocuğun kendisine ait bir miktar parası olduğu için, onu ev dışında çalışmaya ilk defa zorlayan "birleşik aile kimliğinin" erozyonunu durdurmak güçtür. Bu tek bir seferde ve aniden olmaz; aksine bu, genci cezbeden ve tüm çevresini kuşatan, zevk krallığını yaratmış eğlence toplumunun parçası olan anlık ürün ve kandırmaca görüntülerinin olduğu bir dünyada, çok hızlı bir biçimde olacaktır. Hatta bu sürecin ilk evrelerinin aile-çocuk ilişkileri, kültürel süreklilik ve toplumsal cinsiyet rolleri ile ilgili konularda ciddi bozulmalara neden olması olasıllğ 1 bile vardır. Gençlere sunulan çekici şeyler açısından bakıldığında, İslamcı toplum benzeri kimi toplumların bu değişimlere çok güçlü bir biçimde direnç göstermesi olasilığı olsa da, Birleşik Devletlerdeki göçmen gruplarda olduğu gibi, küreselleşmeye hazır olsun olmasın, tüm toplumların er ya da geç bunlardan etkilenecek olmaları olasıdır ${ }^{13}$.

$\mathrm{Bu}$ noktada, dikkatinizi çekmek istediğim ikinci alana yani oyun sorunsalına geçebiliriz. Yetişkinler için oyun ve iş elbette ki, birine harcanan enerji, diğerinden çalınan zamandan kurtarılabildiği için madalyonun iki yüzü gibidir. Ancak 19. yüzyıl boyunca Batıdaki genç insanlar için oyun, işten çalınan zaman olarak değil, aksine kesinlikle çocukluğa ait bir yapı olarak tanımlanmıştı. Oyunun gençlerin gözündeki bu anlamı, tarihsel olarak iki temel kaynağa dayanır. Aslında işle ilgili tartışma sırasında, her ikisine de değinmiştik. 19. yüzyılda oyuna verilen bu önemin nedeni, oyunu gelişim, öğrenme ve toplumsallaşmanın alanı olarak görmeye başlayan, Friedrich Froebel, Maria Montessori, G.Stanley Hall ve John Dewey gibi çocukluk ve eğitim alanında çalışan kişiler sayesinde kökleşen, yeni ve farklı çocukluk değerlendirmeleridir. Çocukluğu konu 
alan bir bilimin kurucuları olan bu kişiler, araç yapan insanın (homo faber) yerine çocukluk donanımının temeli olan oyun oynayan insanı (homo ludens) koymaya başladılar. İşte bu noktada, Rousseau'nun oyunu sadece bir enerji biçimi değil eğitimin merkezi olarak da gören görüşleri, Locke'un görüşlerini gölgede bırakmaya başladı.

Oyun önceleri işi ertelemenin bir yolu olarak günün belli zamanlarıyla, okuldan sonra, oyun alanları ve jimnastik salonları ile sınırlandırılmıştı. İtalyan annelerin, ilk defa okulun yanından geçerken gördükleri okul etkinliklerinin bu ilk biçimi, onlanı kesinlikle çocuklarının Amerika'da öğrendikleri şeyler konusunda rahatsız ve mutsuz etmiştir. Bununla birlikte, 20.yüzyılda Amerikan okulları öğretime ilerici yaklaşımları uyarlarken, oyun da müfredat programlarına girmeye başlamıştır. Çocuklara, yetişkinliğe hazırlığın bir parçası olan eğitim amacıyla işten uzak daha fazla zaman verilirken, okullar da oyunu, öğrenmenin kendisi ile ilişkilendirerek tanımlamaya başlamıştı. Önceki katı plan ve denetimlerden arındırılan sınıflara daha çok oyun zamanı ve oyun mekanı girdi ve sonuç olarak öğretim yeniden biçimlendirildi. Amerikalılar, 19.yüzyılda çok sık1 çalışırken 20.yüzyılda daha çok oyun oynamayı öğrendiler. Oyuna bu kadar önem veriliyor olması, modern Amerikan kültürünün dik kafalı olduğu izlenimini vermiş ancak oyuna, çocukların eğitimi sürecinde dünyanın başka hiçbir yerinde bu kadar yoğun bir biçimde yer verilmemiştir. Amerikan okulları, babalarının garajlarında yeni iletişim biçimleri yaratan, dünyanın en yaratıcı pek çok çocuğunu yetiştirmiş, ama aynı zamanda birçok da denetimsiz sınıf ve eğitilmesi zor çocuk yaratmıştır. Dünyanın değişik bölgelerinde gözlenen küreselleşme bağlantılı kaygıların bir kısmı, kesinlikle, eğitimde bilgisayara ve internete uyumdan sonraki aşama olan ve Amerika'nın "denetimsiz" eğitim sisteminin ürünü olan birtakım değişikliklerin yapılması zorunluluğundan kaynaklanır.

Birleşik Devletlerde çocuklara özgü özel oyun biçimleri, serbest piyasa ekonomisinin, engel tanımaz gelişiminin sonucudur; ancak bu ekonomi, hem enerjinin boşaltılması için uygun bir yol olduğu düşüncesini, hem de çocukluğun öznel olduğunu ileri süren yeni görüşü destekleyen yeni oyun alanları da yaratmıştı. Oyun ve eğlence, dikiş makinalarında ve torna tezgahlarında ya da dükkan ve fabrikalarda saatlerce, her geçen gün daha da ağırlaşan koşullarda çalışan ve çıraklıklarının ilk zamanlarında gayri resmi de olsa çok fazla meslek eğitimine zamanı olmayan ergenler için özellikle anlamlı olmuştu. İşin bir tamamlayıcısı olan, toplumsal ritüellere ve evişleri ile bağlantılı oyuna benzemeyen, temelde geleneksel toplumsallaşma modellerinin tamamlayıcısı olan bu oyun çeşidi, parçalara ayrıldı ve sonra da ticarileşti. Jane Adams bunun tehlikelerini "Şehir Sokaklarında Dolaşan Genç Ruhu" adlı kitabında açık bir biçimde anlatmıştı ${ }^{14}$. Ticaret, bir tarafta çocukların çalışmasından yarar sağlarken, çocuk ve ergen oyunlarından sağlanabilecek kazançları kısmen de olsa görmeye başlamıştı. Çocukların çalışması sorunu benim önerdiğim gibi, küresel bağlamda tartışılan bir konu haline gelirse çocuk oyunlarının büyük bir patlama yaşaması olasılığı artacaktır. Bu noktada, piyasa hareketleri ve yeni iş alanları ile tanımlanan para temelli ekonominin sonuçları; ifade özgürlüklerinin anababalar tarafından sınırlandırıldığ 1 geleneksel çocuk anlayışı, gencin iş saatleri dışında geldiği bu yeni yerlere duyduğu ilgi ve aynı çocuklardan video 
dükkanları ile hamburgecilerde elde edilen kazançlar üçgeninde çok yoğun çatışmalara neden olacaktır.

Oyun ve onunla bağlantılı nesneler, ticari dünyamızda daha fazla yer elde ettikçe onların çekiciliklerine karşı koymak da zorlaşacaktır. Günümüzde Batının, zengin çocuklara, hatta tek çocuk yasağının olduğu Çinli şehir sakinlerine sunduğu oyuncak ve eğlence olanakları, yeni bir eğlence alanı olmuştur ve gelecekte bunlar, yüksek ücret elde etme isteğini ve Batının sağladığı olanaklara yaklaşma arzusunu uyaracaktır. Oyun ve işin birlikte, geleneksel kuşaklararası ilişkiler, kültürel süreklilik ve bunlara uygun birçok çocukluk tanımının yeniden gözden geçirilmesine neden olması olasılığı oldukça fazladır.

\section{Cinsellik ve Çocukluğun Sınırları}

Bu noktada, küreselleşmenin etkilediği çocuklukla ilgili bir başka konuya geldik. Bir çocuk her şeye karşın nedir? 20.yüzyılın başlarında Birleşik Devletlerde, çocuklukla ilgili görüşlerimizi değiştiren özellikle anlamlı ve sembolik iki hareket gerçekleşmiştir: Birincisi, bugün onlu yaşlar dediğimiz gelişim dönemindeki çocukların eğitim görme süresinin yukarı doğru bir ilerleme göstermesiydi; ikincisi ise, bir eyaletin kızların cinsel olarak etkin olabilme yaşını yükseltmesinden sonra bir başkasının bununla ilgili yasa çıkarmasıdır. $\mathrm{Bu}$ iki durum, çocukluğun üst sınırlarının kurumsal düzeyde yeniden tanımlanmasına neden oldu, böylelikle 12-18 yaşlar arasındaki çocuklar hem korunma nesneleri hem de eyalet yönetmeliklerinin özneleri oldular. Kurumsal yöndeki diğer bir değişiklik de, daha uzun bir çocuklukla ilgili bu beklentileri ifade etmeyi mümkün kılacak pek çok yolun oluşmasını sağlayan çocuk mahkemesi sisteminin hızla gelişmesidir. Küçüğü eylemleri ile ilgili suç sorumluluklarının tamamından korumak için tasarlanan mahkeme, onlu yaşlardaki çocukların yapmaması gerektiği düşünülen eylemlere yönelik hükümleri yürütme aracı oldu. 20.yüzyılın ikinci yarısında, bütün olarak çocukluk, öncü psikolog ve eğitimci Stanley Hall'ın 1904'deki iki ciltlik muazzam çalışmasında "ergen" adı ile kutsallaştırdığı bir yaşam dönemini içerecek biçimde büyük oranda genişletilmiştir. Bunun sonucu olarak, her ne kadar iki statü (çocuk ve ergen) arasındaki evre, birinin diğeri içinde nasıl gelişebildiğini göstermek için ifade edilmişse de, Birleşik Devletlerde ergenlik yetişkinliğe hazırlıktan çok çocukluğun uzatılması anlamına gelmiştir.

Liselerde açıkça desteklenen, büyük yaştaki ergenlerin katılımı ile daha da güçlenen özgürlük taleplerinin ortaya çıkması ve çoğunlukla 14-18 yaşlar arasındaki farklı yaş gruplarındaki gençleri kapsayan ve bir genç kızın cinsel ilişkiye girmesini suç kabul eden yeni yasaların düzenlenmesi, daha uzun bir çocukluk için hem sembolik hem de etkili araçlar olmuşlardır. Bunun yanında, çocuklukla ilgili bu yeni tanımlardan dolayı özellikle göçmen ailelerin çocuklarının mahkemelere daha fazla sevk edilmeleri sürpriz olmayacaktır ${ }^{15}$. 19.yüzyılın ikinci yarısında çocuklukla ilgili paradigmalar doğrultusunda gelişen duyarlılık ve görülen değişmeler, eski dünyadan gelenlerin "sancılı bir dönem" olarak düşündükleri yeni bir yaşam evresinin oluşmasına da neden olmuştu. Günümüzde, Batının çocuklukla ilgili görüşleri, çoğunlukla Erik Erikson'un "yetişkin sorumluluklarını erteleme" olarak adlandırdığı ergenlik görüşüne dayanır. Bunun aksine, ergenliğin 
dönüşümlü niteliğini kısmen görebilen ya da tam olarak göremeyen dünyanın geri kalan pek çok bölgesi, uzayan bir ertelemeyi güçlükle kabul etmektedir.

Ergenliği çocukluğa bağlayarak, cinsel olarak güçlü ve özellikle de cinsel enerji ile dolu bir yaşam dönemini çocukluğun içine çekmiş olduk. Ergenliğe özgü bu cinsel olgunluk, geleneksel toplumlarda genellikle kabul görse de yine de temkinli bir yaklaşım söz konusudur. 20.yüzyılda Birleşik Devletlerde açgözlü piyasa ekonomisinin etkili olduğu, oyun ve aynı zamanda toplumsal cinsiyet eşitliğinin vurgulandığı bir ortamda, güzellik, yaşam enerjisi ve modanın temsilcisi olarak görülen ergenlerin, kültürel bağlamda rahatça hareket etmelerine izin verilmişti. Sonuç olarak, ergen imgesi, Batı reklamlarının ve hepimizin bildiği gibi cinselliğin satıldığı popüler kültürün özel ilgisini çekmişti.

8 ile 14 yaşları arasındaki bireyleri kapsayan çocukluk döneminin sınırlarını çizmenin çok güç olması nedeniyle, zamanla çocuk cinselliğinin belirsiz statüsünün aslında olağanüstü bir biçimde tartışmalı ve duygusal olarak da zengin içerikli bir konu olduğu anlaşılmıştır. Bununla birlikte Amerikalıların ergenliği, korunan çocuk masumiyetinin genişleyen paradigması içine yerleştirmeye başladıkları dönemde Freud, bebeklerde bile var olan temel cinsel gücü yeni yeni keşfediyordu. Masumiyet şemsiyesi altında korunan yaşın ve cinselliğin değişime açık bütünleşmesinin, kültürel politikaları ve hatta kültürel kaygıları hedefleyen güçlü bir alan yaratması kesindi. Böyle de oldu. Günümüzde, dünyanın tersine gittiğine yönelik duygumuzu kışkırtmak için, çocukların cinsel amaçlarla sömürülmesini göstermekten daha etkili bir yol yoktur. Sonuç olarak küreselleşmeye bağlı sorunların işaretlerinden biri olarak, biz her zaman cinsel olarak sömürülen çocuklar görmeyi bekleyebiliriz.

Ergenliğin çocuklukla birleştirilmesi eğiliminin başka sonuçları da olmuştur ve bunlar en iyi biçimde küçük çocukların, konuşma biçimleri açısından kendilerinden daha büyük çocukları taklit ettiklerinde yaşadığımız tedirginlik düzeyinden anlaşılır. Günümüzün gelişen dünyasının küçük çocuklarının, ailelerinden çok akranlarını taklit etme (konuşmalarını, giyimlerini, dil ve boş zaman alışkanlıklarını) olasılıkları daha fazladır ve bu modeller, küçük çocukların yaşamına gittikçe daha fazla girmektedir. $\mathrm{Bu}$ eğilim, aile ve öğretmenlerden değil popüler medya ve popüler kültürden gelen ipuçlarıyla hareket eden çocuklarda görülen bir özelliktir. Sonuç olarak bu noktada, oyun ve cinselliğin küresel ufkumuz üzerindeki güçlü birleşme noktalarına ulaştığımızı düşünüyorum. Günümüzde hiçbir şey, genç odaklı Amerikan popüler kültürünün genel, hızlı ve durdurulamaz yayılışının bir sonucu olarak yaşadığımız, küreselleşme ve çocuklarla (fuhuş yapmayan, kötü şartlardaki fabrikalarda çalışmayan ve tecavüze uğramayan çocuklar) ilgili kaygılı zihinsel temsillerimiz kadar korkunç değildir. Temelde ilgilenilen şey, potansiyel kazanımın dünyadaki tüm çocuklar olduğu, en çok genç kültür için uyarlanan müzik, müzik klipleri, beden stilleri, giyim ve süslemeleri içeren Amerika temelli şiddet, cinsellik ve kendiliğindenlik biçimleridir. Böyle olunca çocuklarımız, denetimimiz altında diye düşündügümüz kendi dünyamıza isyan ediyor ve onu tehdit ediyor görünüyorlar, bu durum dünyanın hiçbir yerinde küreselleşmenin zorlukları ile yeni yeni karşı karşılaşan ülkelerdeki kadar yoğun değildir. 
$\mathrm{Bu}$ saplantılı görüşe kapılmadan önce, yazının başında söylediğim şeyi hatırlatmakta yarar var. Çocuklar kültürümüzde çok büyük bir sembolik yük altındadırlar ve genellikle en güçlü, kendi kendimizi korkutma aracıdır. $\mathrm{Bu}$, en fazla Batı değerlerinin yayılmasına karşı çıkanlarca çizilen ve karşıtlarının iddiasına göre de küreselleşme arzularımızın başlattı̆̆ 1 sözde "uygarlıklar çatışmasının" nedeni olan betimlemedir. Bu betimleme, kesinlikle Batıya ve onun kendini hoşgörme ve bozulma odaklı zorlamalarına, büyük bir güçle direnç gösterilmesini sağlayacak en güçlü cesaret verme aracıdır. $\mathrm{Bu}$ resim pek çok açıdan, Batının gence gösterdiği özel ilginin sonucu olarak 19.yüzyılın masum gencini korkunç bir hayalete dönüştürüşümüzün resmidir. Sonunda, tartışmamızdaki o noktaya ulaşmış olduk. Kendimizi bize ait kabus ve yansıtmaların tuzağına düşürmeden önce, küreselleşme sonunda çocuklara olacaklarla ilgili beklentilerimizi, 20.yüzyılda çocuklarımıza yüklemeyi öğrendiğimiz sembolik özelliklerin duygusal olarak beslediği bu belirsiz imgeden kurtarmak için duraklamakta yarar var.

20.yüzyılın sonunda Amerika'da ortaya çıkan bu şaşırtıcı ve ergenliği çok fazla cinselleştiren genç hayaleti, dünyanın geri kalan pek çok yerindeki insanlar için önemsiz bir tehditti. Çocuklara gelecekte ne olacağı, her bir bölgenin özel kültüründen, piyasaların büyüme hızından ve her toplumun açık bir biçimde Batı değer ve inançlarına uyum sağlama isteğinden etkilenecek ve etkisi azaltılacaktır. Bu denemede tartıştığım gibi, Amerika ve Batıya ait inanç ve değerler, belli bir zaman ve mekanda oluşmuştur ve büyük olasılıkla küreselleşen yeni ekonomik pazarın sonucu olan kimi değişimleri anlamamızı sağlayan piyasa büyümesi ile açıça tatmin edilseler de aslında sadece ekonomik alandaki gelişmelerin sonucu değildirler. Kendi çocuklarımızın onlara yüklediğimiz sembolik özelliklerin kurbanları olmalarına izin vermeyeceğimiz gibi, dünyanın geri kalan bölgelerindeki çocukların da bu imgelerin kurbanları olmasına izin vermemeliyiz. Bununla birlikte, Amerikanın yaşadığı deneyime atıfta bulunarak tartıştı̆̆ımız kimi ekonomik büyüme modellerinin, eğer değişmez değillerse, en azından Amerika dışındaki diğer toplumlarda da görülmesi olasılığı vardır. Amerika dışındaki toplumlarda yaşayan çocukların yaşamında küreselleşme sürecinde görülmesi olasıllı̆̆ yüksek olan değişikliklerin yeniden incelenmesi önemlidir.

İlk olarak, iş konusunda: Büyüme uzmanları, bu süreçteki yayılmanın nasıl olabileceği konusunda birbirlerinden farklı görüşlerde olsalar da, çocuklar, küresel pazar güçlerinin girdiği her yerde, çok dikkat çekici bir biçimde, büyük olasılıkla para ekonomisinin tuzağına düşeceklerdir. Bu başlangıçta, aile içindeki rollere ek olarak ve ailelerinin yararı biçiminde ortaya çıkarken (gerçekten de haberlerdeki hikayelerde gördüğümüz gibi, çocuklar ailelerinin iyiliği için satılabilmektedirler) iş de, kendi kendine iki şeye yol açacaktır: Birincisi Batı duyarlılığının çalışan çocuklar nedeniyle yara almış olmasının kuşku götürmemesi ve bunun farklı denetim yöntemleri oluşturma çabalarıyla ifade ediliyor olmasıdır; ikincisi ise paraya dayalı bir ekonominin, çocukları ilk defa ücretli bir işe sokan aileyle olan bağları belirli bir düzeyde de olsa zayıflatacak olmasidir. 
Bunların sonunun nereye varacağını kestirmek güç. Bu, toplumların kendilerine özgü pek çok özelliğine bağlı olduğu gibi, evrendeki iş alanlarını düzenleyen uluslararası ticaret kuruluşlarının gelişim hızına da bağlı olacaktır. Ayrıca bu, evrensel refah düzeyinin artış hızı ve zamanlamasına olduğu kadar birçok politik karar ve şarta da bağlı olacaktır. Ancak hızı ya da derecesi ne olursa olsun, bu süreç içerisinde kimi geleneksel toplumsal cinsiyet bölünmelerinin sorgulanacak olması kesindir ve bu, hem dirence hem de korkuya neden olacaktır.

Oyun konusunda: Oyunun temel özelliğinin, Yeni Küresel Dünyanın üyesi olan toplumların pek çoğunda değişmeyeceğine inanmak, hem Batının çocuklukla ilgili betimlemelerinin çok ileri düzeyde olmasının bir sonucu olarak, hem de küreselleşmenin yapısına dahil edilen ticari oyun olanakları nedeniyle imkansızdır. Gelişen dünya, pek çok Batı temelli oyuncak yaratmakla kalmayıp onların tüketilmesini her geçen gün daha da fazla isteyecektir ve bunu yaparken çocukların, yarattığı oyuncakların olumlu yönlerinden yararlanmasını da isteyebilir. Oyun, 19.yüzyıl çocukluk anlayışının yeniden yaratılması için çok temel bir başlangıç noktası olsa da dünyanın başka bir yerinde yaşayan pek çok çocuğun da yaşamının temeli olarak nasıl tam olarak benimsenebileceğinin net olmadığ bir Batı kültürü ürünüdür. Tamamen benimsemek, özünde Batı kültürüne bağlanmak olacaktır. Üstelik oyun bugün Birleşik Devletlerde bile çocuk eğitiminde aşırı izin verici tutumlardan kaygı duyanlarca ve küresel rekabetin, oyuna yatkın çocuklarımızı, eğitme ve disipline etme sorumluluğumuzun sonucu olarak çok katı standartlara uymaya zorlamamızı gerektirdiğine inandırılanlarca hoş görülmemektedir.

Bir çocuğun kim ve ne olduğunu tanımlama konusunda: En fazla tahminin bu noktada yapıldığını düşünüyorum. Çocukluğun yaşamın daha ileri yaş dönemlerini içerecek biçimde uzamasının, toplumsal olarak maliyeti yüksektir ve çocukluğun en üst sınırını gösteren şey de özellikle eğitimdir. Üstelik Birleşik Devletlerde bile, tam bağl1lıktan ergenliğin yol açtı̆̆ koruyucu masumiyete gerileme sürecinin başlangıcına ilk defa tanıklık ediyoruz. Bunun açık bir örneği, genç insanları yetişkinler için düzenlenen hapishanelere atma istekliliğimizin artmasıdır. Dünyanın geri kalan bölgelerinde, çocukluğun nasıl korunabileceği ile ilgili yeni bir duyarlılığın oluşması olasıdır ve bu bölgelerde, geleneksel olarak tanımlanan çocukluk döneminden ergenliğe nasıl geçileceği ile ilgili sorular artacaktır. Bunun Amerika'da görüldügü gibi çocukluğun daha ileri yaşlara doğru itilerek genişlemesi anlamına gelip gelmeyeceği, her toplumun refah düzeyine, eğitim süresini ne kadar uzattığına ve o toplumun kültürüne özgü diğer faktörlere bağlı olacaktır. Sonuç olarak, dünyadaki her toplumun, cinsellikle ilgili kendine özgü ve diğerlerinden farklılaşan görüş ve uygulamalarının olması nedeniyle, bu toplumların çocuk cinselliği konusunda, bence çocuklukla ilgili şu anki görüşlerimizde yer alan masumiyet ve cinsellik bütünleşmesinin yarattığ sorunlu gerginliği, tekrar tekrar yaşayacağını bekleyebiliriz. $\mathrm{Bu}$ toplumların pek çoğunda, çocukların cinsellikle kuşatılması için Freudcu bir devrime gerek kalmadı ve pek çoğunda da masumiyet, cinsel deneyim yokluğu ile eşleştirilmiyor olabilir. Bu noktada, Batı, çocukları ele alış biçimi açısından kendi içinde çok büyük farklılıklar ve ikiyüzlülükler göstermesine karşın (özellikle ergen cinselliğinin ticarileşmesinde), görünürdeki çocuklara çok fazla yatırım 
yaptığı için, yanlış anlamalara neden olabilecek pek çok alanla da karşı karşıya kalacağız. Çocukların cinsel sömürüsü, öfkeyi ifade etmek için öğrenmiş olduğumuz en hassas suç yollarından biri olduğu için, günümüz dünyasında, bununla incitilmeye devam edeceğiz. Ancak ben çocukların cinsel olarak istismar edilmesi olgusunun, dünyada küreselleşme olsa da olmasa da değişeceğinden emin değilim.

Tarihçiler, geleceği tahmin etmeye başladıklarında adları kötüye çıkmış korkaklardır ve ben buradaki görüşleri tarihçilerle ilgili genel uyarılarla birlikte sunuyorum. Aynı zamanda tarihçilerin, küreselleşme ile ilgili şu anki tartışmaların bütünüyle içerisinde olmaları gerektiğini ileri sürüyorum. Tahminlerinin doğruluk düzeyi ne olursa olsun, tarihçilerin bilgileri varolan sürecin yapısı ile ilgili eksiksiz analizler yapılabilmesi için gereklidir. Sonuç olarak, küreselleşmeyi küreselleşme ile ilgili kültürel politikaları ve küreselleşmenin toplumsal sonuçlarını, bu tartışmanın içinde yer alan çocuklar olmaksızın tartışmak gerçekten çılgınlık olur. Ben bunu yalnızca bir duygusallık ifadesi olarak söylemiyorum, küreselleşme sürecinde olacakların pek çoğunun ve karş1 çıkılacak ve eleştirilecek pek çok yolun merkezinde çocuklar olacağı için söylüyorum. Eğer küreselleşme, geleceğin ekonomileri, toplumları ve kültürleri ile ilgiliyse, çocukların ve çocukluğun geleceği ile ilgili olduğu kadar çocuklukla ilgili son 50 yıllık dönemde öğrendiğimiz şeylerin tamamını göz önüne alma sorumluluğu ile de ilgilidir.

\section{Dip Notlar}

${ }^{1}$ Daha geniş bir tartışma için bakınız: Culture Matters: How Values Shape Human Progress, Editörler: Lawrence E.Harrison ve Samuel P. Huntington (NewYork, 2000).

2 Özellikle etkili bir versiyonu Sebastiao Salgado'nun Migrations: Humanity in Transition'dur (Aperture, 2000). Salgado'nun fotoğrafları, gerçekten başarılı bir sergi olarak ülkenin tamamını dolaşıyordu.

${ }^{3}$ Paula S. Fass'nın Kidnapped: Child Abduction in America (Newyork, 1997); Philip Jenkins'nin Moral Panic: Changing Concepts of the Child Molester in Modern America (New Haven, 1998)'ya bakınız.

4 Alexander Hamilton'un (1795) Report on Manufacture'deki konuyla ilgili açıklamalarının olduğu bölümleri Paula S. Fass ve Mary Ann Mason'un editörlüğünü yaptığı Childhood in America'nın (New York, 2000) 248. sayfasında bulabilirsiniz.

${ }^{5}$ New England'ın ilk dönemlerindeki endüstri işçileri için Thomas Dublin'in Woman at Work (New York, 1983) adlı kitabına bakınız.

${ }^{6}$ Bakını. Viviana A. Zelizer, Pricing the Priceles Child: The Changing Social Value of Children (NewYork, 1985).

${ }^{7}$ Masum çocuk hakkında kapsamlı pek çok şey yazılmıştır. Bunun için Anne Higonnet'in Pictures of Innocence: The History and Crisis of Ideal Childhood (Londoz, 1998); James R. Kincaid'in Child-Loving: The Erotic Child and Victorian Culture (New York, 1992) adlı kitaplarına bakınız.

${ }^{8}$ Harrison ve Huntington'un kültürün küreselleşme ile ilgili konular üzerindeki etkisi ile ilgili tartışmalarına bakınız. Tartıştığım şey, kültürün kimlerin küreselleşeceğini 
tanımlayacağı ile ilgili olmaktan çok küreselleşmenin, çocuk ve kültürün özelikle uluslararası pazara çekildikleri yerlerdeki sonuçları ile ilgilidir.

${ }^{9}$ Ayrıca bakınız : Linda Gordon'un Heroes of their Own Lives: The Politics and History of Family Violence (New York, 1988); Mary Odem'in Delinquent Daughters: Protecting and Policing Female Sexuality in the United States, 1885-1920 (Chapel Hill, 1995).

10 Lionell Trilling, The Liberal Imaginations: Essays on Literature and Society (NewYork, 1950). Günümüz çocuklarını ele alan ilişsili bir bakış açısı için bakınız: Tobias Hecht, At Home in the Street: Street Children in Northest Brazil (Cambridge, England, 1998).

${ }^{11}$ Alintılar;

Lassonde, Stephen (summer 1996). Learning and Earning: Schooling, Juvenile Employment, and the Early Life Course in Late Nineteenth-Century New Haven, Journal of Social History, 29, 846.

Lassonde, Stephen (spring 1998). Should I go, or Should I stay?: Adolescence, school Attainment and Parent-Child Relations in Italian Immigrant Families of New Haven, 1990-1940. History of Education Quarterly, 38, 49'dan yapılmıştır.

${ }^{12}$ Lassonde, "Should I go or Should I stay?", 52.

${ }^{13}$ Bat1 etkilerine yönelik İslami direnç sorunu için bakınız Samuel Huntington, The Clash of Civilizations (New York, 1998). Elbette ki Huntington, küreselleşmenin, dünyanın güçlü ve yarışmacı uygarlıklarının sunduğu alternatif yaşam kural ve biçimlerinin olduğu bölgelerinde yaşanmayacağına inanıyor. İslamcı toplumlar kesinlikle, batı toplumlarının sunduğu zevk ve oyun elementlerinin hepsine çok katı bir şekilde karşı çıkmış olan toplumlar arasında olmalarına rağmen, ben genel olarak küreselleşmenin bir yayılma süreci olduğu görüşünden çok Huntington'un küreselleşmenin bir uygarlıklar çatışmasına yol açacağına ilişkin görüşüne daha yakın duruyorum.

14. Jane Addams, The Spirit of Youth and the City Streets (ilk bask1, 1909; ikinci bask1, The University of Illinois Press, 1972). Ergenlerin eğlence kültürleri ile ilgili olarak ayrıca bakınız: Kathy Peiss, Cheap Amusements: Working Women and Leisure in Turnof-the-Century New York (Philadelphia, 1987); David Nasaw, Children of the City: At Work and Play (New York, 1985). Bu konuyla ilgili farklı görüşler için (gerçekte Addams'ınkilere yakın olan), bakını: John Burnham, Bad Habits: Drinking, Smoking, Taking Drugs, Gambling, Sexual Misbehavior, and Swearing in American History (New York, 1993).

15. Bakınız: Odem ve Eric C. Schneider, In the Web of Class: Delinquents and Reformers in Boston, 1810s-1930s (New York, 1992). 